\title{
ALBANIA-GREECE SEA ISSUE THROUGH THE HISTORY FACTS AND THE FUTURE OF CONFLICT RESOLUTION
}

\author{
Senada Reci ${ }^{\star}$ \\ University "Luigj Gurakuqi" - Shkoder, Albania \\ ORCID iD: https://orcid.org/0000-0003-2174-6787 \\ senada.reci@unishk.edu.al

\section{Luljeta Zefi} \\ University "Luigj Gurakuqi" - Shkoder, Albania \\ ORCID iD: https://orcid.org/0000-0002-9718-0065 \\ luljeta.zefi@unishk.edu.al
}

\begin{abstract}
The issue of the sea between Albania and Greece has been and continues to be an object of study for various authors. Research shows so far that many studies have tried to go slightly from the descriptive to the explanatory and analytical framework and have generally fallen into the 'trap' of subjective approaches creating the phenomenon of nationalism. That appears in different forms, damaging the spirit of friendship and cooperation between both countries. This paper analyzes relations between Albania and Greece and their evolution based on international acts until the decision of the Albanian Constitutional Court annulling the agreement between them on the issue of the sea as incompatible with the constitution in terms of absolute objectivity. The demands of the Greek state for extension with 12 miles under the magnifying glass of the interpretation of the norms of the international law of the sea, the principle of equality and equity are part of the insistence on gaining superiority in the sea area vis-à-vis Albania. All this leading to the dialogue for another treaty cooperation and friendship occupy a vital part of the facts, which constitute an ongoing open discussion about the future of the sea issue on the Hague International Court.
\end{abstract}

Keywords: Sea Issue; Agreement; Constitutional Court; Decision

\section{INTRODUCTION}

The issue of the sea began to be discussed and negotiated when Greece was declared a strategic ally by Albania that specifically in 2001, introduced in its foreign policy program the definition of Greece as a strategic ally (Murati 2013, 32). It means that the relations between the two countries were of strategic importance for Albania. This fact was 'exploited' by Greek diplomacy because the latter had never expressed any strategic preference for strategic relations with Albania, evidence that Athens neglects Tirana's importance to bilateral ties. The genesis of the maritime issue can't be related to 
genuine legal motives. State borders are clearly defined in international acts and accepted by both countries even after establishing diplomatic relations in 1971. It is not related to reasons, either actual political or diplomatic. Logical reality leads to economic and energy motives and interests, as the discovery of hydrocarbon-rich basins in the maritime areas of Albania and near Albania, which give birth to and promote the Greek strategy of efforts for geographical changes of state borders, marine and the definition of marine areas. There must be a willingness to cooperate and dialogue. There are many examples, but in Southeast Europe, we can take as typical examples the talks on the maritime borders between Croatia and Slovenia, which have lasted almost three decades (Zaganjori 2021, 184). If these do not work, then international conflict resolution mechanisms seem to be the best alternative, so it was evaluated and selected by the two countries' governments. In these circumstances, pending a review by international mechanisms, specifically by the International Court of Justice in The Hague, we only have to make a chronology of historical events and legal acts that will affect the analysis of its decision.

\section{ALBANIA-GREECE RELATIONS AND THEIR EVOLUTION BASED ON THE INTERNATIONAL ACTS AND AGREEMENTS}

Acquaintance with international documentation starts from the London Conference of August 1913 with the decision of the Great Powers 'On the demarcation of the borders of Albania with Greece', to continue with the Florence Protocol on January 27, 1925 'On the borders of Albania with Greece' and 'The Final Act of Delimitation of the Borders of Albania', drafted and decided at the Conference of Ambassadors in Paris on July 30,1926, signed at the same time by the representative of Albania, Greece, and Yugoslavia (Puto 2001, 85). Despite the dissatisfaction of both Albania and Greece with these international acts, it is important to emphasize their conclusions: first; that international acts on borders have been decisions of the Great Powers, and they are irrefutable binding and deposited in international organizations such as the League of Nations and later the United Nations (Puto 2001, 85), secondly; the Greek government has officially signed the international acts of delimitation of borders Albania and has legally recognized the borders of Greece with Albania. Based on these historical legal facts, the discussion on maritime borders is rejected by the Constitutional Court of Albania, arguing that maritime boundaries between the two countries have existed and are defined in international legal acts. So legally sanctioned is the border between Albania and Greece in land and sea. Greece had never reclaimed this border even when there were no diplomatic relations between the two countries, and both did not recognize each other as subjects of international law.

Even in the tensest periods between them, which have several times reached the brink of armed conflict in August 1949, Athens did not formally express territorial claims 
and demands for the change of land and sea borders with Albania. Borders between the two countries are defined by the Florence Protocol (Puto 2001, 85). Greece had officially recognized the borders of the Albanian state since it, together with other Balkan states, signed the Peace Treaty with the Ottoman Empire on 30 May 1913 (Poincaré, 2006, 494). In Article 3 of the Treaty, the signatory parties agreed to entrust to the Great Powers the issue of border regulation and any other issue that had to do with the new state of Albania (Poincaré 2006, 494). Thus, since May 30, 1913, Greece and other Balkan states had given up their claims to be a party in the demarcation of the borders of Albania and were forced to accept and respect the Great Powers' decision. According to the norms of international law, they have voluntarily chosen to obey the findings of the Great Powers for the borders of Albania. On March 5, 1914, at the session of the Chamber of Deputies in the Greek Parliament, the Prime Minister of the country Venizelos declared Greece should submit to the Great Powers' decision regarding the borders of Albania (Dushku 2021, 252). While other Balkan states, with the Treaty signed in London a year ago, had entrusted them with the solution of this issue (Dushku 2021, 252).

Greece international legal commitment to accept the borders of the new Albanian state in 1913 it was also confirmed by the Greek scholar: "Greece agreed that the terms of peace with Turkey should include a statement that Albania's future status and organization need leave entirely to the Great Powers" (Condis 1976, 98). Statements of the diplomatic mission of Greece at that time proved acceptance of these borders (Archive of the Ministry of Foreign Affairs 1923, 136, 9/1). With the establishment of the communist regime in Albania, the two countries did not have diplomatic relations. Still, even in these times, the two sides held talks and finally agreed on the signing on February 8, 1958, of the 'Protocol concluded between the representatives of the People's Republic of Albania and the Kingdom of Greece' on the breach of the Corfu Channel (Archive of the Ministry of Foreign Affairs 1958, 6). After the restoration of Albania's diplomatic relations with Greece in May 1971, the governments of the two countries will begin negotiations for the signing of a joint treaty finalized on March 21, 1996, as the 'Treaty of Friendship, Cooperation, Good Neighborliness and Security between the Republic of Albania and the Greek Republic'. Both "states declared their respect for the principle of sovereignty, territorial integrity, equality of rights" (Treaty 1996, article 1). This Treaty can be considered the highest official and legal document of both sides that confirms the acceptance of the borders between the two countries by the respective governments. If we move on to the analysis of some of the essential national acts of the Albanian state that reconfirm the borders of the Albanian state:

- Decree of the People's Assembly No. 3321 dated 01.09.1961 'On territorial waters and inland waters of the People's Republic of Albania';

- Decree of the People's Assembly No. 4650 dated 09.03.1970 entitled 'Above the border of the People's Republic of Albania' which stipulates that: "the territorial waters of the People's Republic of Albania extend along its entire coast, in a 
width of 12 nautical miles starting from the straight line and in the middle of the strait of the Corfu Canal"; and

- Decree of People's Assembly No. 5384 dated 23.02.1976, which undertook a change in the width of the territorial waters from 12 miles to 15 nautical miles which define the baseline of the cape of Rodin (Muzhli) to through the Corfu canal (Decree 5384, 1976).

We constantly confirm the primary straight line of the sea border through official decrees of different times. The Albanian legislation reflects it even after the changes of political regimes, proving that the evolution of political regimes does not affect or change the status of the maritime borders known and defined between the two states. Law No. 8771 dated 19.04.2001, article 3 entitled for the state border of the Republic of Albania define that: "the territorial waters extend along its entire coast in a width of 12 nautical miles starting from the baseline, which goes from the cape of Rodon (Muzhlit) and then between the Albanian coast and the islands of the Greek Republic to the Corfu Channel". In 2008, the Parliament of Albania will approve the new law repealing the above rule of 2001, specifically Article 53 of the new law 'On the control and surveillance of the state border' stating that: "The state border of Albania is established and regulated based on international agreements ratified by the Assembly, as well as bilateral or multilateral treaties, concluded with other countries" (Law 9861, 2008 , article 53). Only three years after the signing of the agreement and its abrogation by the Constitutional Court of Albania, the parliament took an initiative to abolish article 53 of the law of 2008 (amended by Law No. 60/2012, 'On an amendment to Law No. 9861, dated 24.01.2008, 'On the control and surveillance of the state border'). In the decision of the Constitutional Court of Albania, point 82.3, sanctions in the legal plan a single truth about the existence of maritime borders between Albania and Greece: "state borders, including, of course, the border of the territorial sea between Albania and Greece, have existed" (CC Decision, 82.3).

The protocol of Florence of 1925, for the delimitation of the southern border of the Republic of Albania, emphasized among others that "the land border crosses the Ionian Sea in the Gulf of Ftelia according to a perpendicular line with the general direction of the coast to the border of territorial waters" (Official Journal of the Republic of Albania 2010,52). The summary of these legal and historical facts presented above leads to an attitude that the Albanian-Greek maritime borders are clearly defined in the International Acts and accepted by the two countries' governments; what is the misfortune of this issue, relates to the intersection of political and economic interests at certain moments by interpreting them under the need of a new agreement of 2009, repealed because it affected the claims of state sovereignty of the Albanian state. 


\section{THE DECISION OF THE CONSTITUTIONAL COURT IN 2010 AND ANNULMENT OF THE SIGNED AGREEMENT BETWEEN THE TWO COUNTRIES}

The debate on the definition of the Albanian maritime border has received public attention only during the last decade with the intervention of the Constitutional Court. The truth is that all possibilities for a new agreement with the Greek state remain open, only under the magnifying glass of the decision of the Constitutional Court, whereas easily as the method to be followed is explained, so difficult remains the negotiation based on it. The Constitutional Court of Albania with Decision No. 15, dated 15.04.2010, declared as incompatible with articles 3, 4, 7 and 92/e of the Constitution the agreement concluded between the Republic of Albania and the Republic of Greece 'On the delimitation of their respective areas, the continental shelf and other maritime areas belonging to it under international law'.

This Decision is final and enters into force on the day of publication in the Official Journal. The Constitutional Court was set in motion by the Socialist Party (opposition party at the time), recognizing it as a legitimate subject in the interest of the case. The trial decided on another issue, the 'power' of the negotiating team of the Albanian government. This point was necessary because the Greek side considers the only fact that 'lags' in the agreement's progress. For this reason, it is up to the Court to examine whether a constitutional body has violated the rights of political parties through a normative act issued by it (CC Decision 2010, 10). In this sense, each state institution must have a clearly defined scope of its competencies to act under constitutional and legal requirements. Article 92 of the Constitution explains the president of the Republic's competencies: "to conclude international agreements according to law". The Court emphasizes that the head of state has the power to exercise its ius repraesentationis omni modae i.e., to make internationally known the internal state will and represent the unity of the state on the international stage. How the president exercises this function can be: by the participation of the president himself, by making known the political position of the state in foreign relations, or by transferring the representative authority, through the plenipotentiary, to other bodies, mainly to the government. Conclusion of agreements where the Albanian state is a party, as a subject of international law, the participation of the president of the Republic is inevitable, either personally or through the plenipotentiary.

From a legal point of view, a representation of the state, as a subject of international law, in foreign relations by the government, without the prior authorization of the president, when it comes to international agreements of a political nature, is not in line with the principle of the state of law (CC Decision 2010, 35).

They are considered representatives of their state, based on their function and without the need to present full powers, heads of state, heads of government, and ministers of foreign affairs, to carry out all related acts, upon the conclusion of a treaty 
(Vienna Convention on the Law of Treaties 1969, articles 7 and 8). Failure of President of the Republic to equip the delegation with full power violates the management of the President of the Republic provided by article 92 of the Constitution, and consequently the principle of separation and balance of powers guaranteed by article 7 of the Constitution (CC Decision 2010, 47).

So, it turns out that the Albanian side has negotiated for a wider object than it was authorized, so exceeding the authorization by the negotiating group and making the agreement incompatible with the principle of the rule of law guaranteed by article 4/2 of the Constitution (CC Decision, point 48). The Court concludes that the agreement signed between the two countries on the delimitation of maritime space violated the requirements of articles 4, 7, and 92/s of the Constitution (CC Decision 2010, 52).

The Greek side maintained its position on the regularity of the 2009 Agreement and the claims for its applicability, not relying on the facts as a whole of international importance but only on the analysis of the Constitutional Court decision on the issue of absolute power negotiating team lacked. In talks with the Greek negotiating team, Albanian deliberately shows the deviation from the primary object and the essence of the agreement on 'delimitation of maritime borders. In addition to the question of the legitimacy of the applicant and the lack of plenipotentiary addressed above, the Court assessed those points of constitutional importance for the case at trial regarding:

1. the title and content of the agreement and the need to define the respective maritime spaces;

2. the application of the principle of strict equality of distance for the division of maritime spaces belonging to both countries;

3. The influence of islands and rock masses in the determination of maritime spaces points to crucial importance for the issue (CC decision, 15.3).

\section{CLAIMS OF THE PARTIES REGARDING THE PRINCIPLE OF EQUALITY AND EQUITY: THE FUTURE DEPENDS ON THE HAGUE}

The evolution of the law of the sea was long based on the so-called doctrine of 'free sea', meaning that all spaces of the seas and oceans belonged to anyone; therefore, they had to be open and accessible for navigation and exploitation for all states without distinction. During the same period, the width of this water belt was determined to be three nautical miles, as at that time, such as the shooting distance (CC Decision 2010, 63). The interest of the coastal states to extend sovereignty and sovereign rights towards the 'open sea' has had as its primary goal the best and exclusive use by them of certain water areas for economic interests, national security, etc. To manage this situation, the UN adopted the Convention on the Law of the Sea in 1982, considered as the 'Constitution for the seas'. The Convention harmonizes the existing norms of international maritime law (treaties and customary international law) 
with the new standards that change or affirm concepts previously unknown and untreated by traditional international maritime law (UNCLOS 1982). According to it, the coastal states have the right and direct interest to take, as the case may be, the necessary steps that make possible the extension of sovereignty, sovereign rights, or national jurisdiction in certain maritime areas (UNCLOS 1982). Based on this international act, regarding the first point, the Court considered it essential that in the function of the case to stop briefly to clarify the meaning, breadth, and legal nature of maritime spaces that fall into the first category, as the open sea is that part of the sea that does not include any of the marine areas mentioned in the first category (UNCLOS, article 86).

The Red Zone is the maritime space following the territorial sea, in which the coastal state has some limited competencies, mainly of an administrative nature. The width of the Red Zone can go up to 24 miles from the baseline, where the width of the Territorial Sea begins (UNCLOS, article 33/2). In this area, the coastal state may exercise various controls to enforce its legislation on customs, fiscal, health, or immigration matters within its territory or its Territorial Sea (UNCLOS, article 33/1).

The concept of Exclusive Economic Zone (EEZ) is considered the space beyond and near the territorial sea and does not exceed 200 nautical miles from the baseline where the Territorial Sea begins. The EEA consists of waters from the water surface to the seabed and the seabed itself and its subsoil (UNCLOS, article 56/1). In the EEA, the coastal state exercises sovereignty rights for economic exploitation (mainly fishing), exploration, etc. The other States, at any time, enjoy the right to freedom of navigation and flight over these waters, the right to lay cables and submarine pipelines, and any other use of it under the offshore regime. For this reason, the EEA generally has a sui generis legal regime (Shigeru 1995, 305).

The definition of the above concepts allows us to distinguish well the description of the Territorial Sea of a coastal state. The ICJ makes clear its position on the issue under consideration regarding the division of the continental shelf in the black sea between Romania and Ukraine, stating that: "the maritime border delimiting the Continental Shelf and the Exclusive Economic Zone should not be confused with the state border dividing territories (ICJ Decision Romania/Ukraine 2009, paragraph 217). For the delimitation of maritime spaces, in most cases, the principle of the middle line was initially applied as a line equidistant at each point from the baseline or the sea coasts of the states concerned (Calfliisch 1997, 213). However, the strict application of this method, both in cases where the shores of the states concerned are opposite (middle line) and when they are attached (equidistant line) to each other, showed that it often did not give a fair and honest result, giving way to case-by-case interpretations, or particular circumstances. Under specific circumstances, at least in the case of the territorial sea, was understood the configuration of the coast, the presence or absence of islands, etc. (Calfliisch 1997, 213). 
In reasoning its decision, the Constitutional Court relied on noting that the ICJ, in its 1969 decision on the delimitation of the continental shelf boundaries in the North Sea between Denmark, the Netherlands, and Germany, emphasized, among other things, that the strict application of the principle of the middle line often creates pronounced inequalities, which increase more and more with the passage from land to sea (CC Decision, 88). Therefore, according to her, in the delimitation of maritime borders, the principles of justice and honesty (equitable principles) should be applied, through which it is possible to reach a fair and equitable solution between the parties.

This position of ICJ would reconfirm in the 1982 Decision on the division of the Continental Shelf between Libya and Tunisia. Furthermore, this decision specifies that "Equity (Equité) is a general principle that should be applied directly as a norm of international law"; therefore, as such, it is mandatory for the Court. Based on the above analysis, the Constitutional Court found that applying only the principle of strict equality in the agreement under trial is contrary to international standards and the obligations arising from article 3 of the Constitution of the Republic of Albania. Precisely, article 1 of the Agreement, among other things, will determine the maritime border between the two countries following the principle of equality, expressed by the midline, each point of which is equidistant from the nearest points of the baseline (both continental and island) from which measures the breadth of territorial sea waters. In this case, the aim is to implement a strict middle line, which does not consider any particular circumstances ascertained when delimiting maritime spaces. Furthermore, this principle will also apply to the demarcation of the borderline between island spaces.

The Court assesses the application of this principle as in open contradiction with the provisions of the UN Convention on the Law of the Sea, the practice of states, and the decisions of international courts or courts of international arbitration (CC Decision 2010, 98). The presence of natural islands is an essential element that significantly affects the delimitation of maritime borders (spaces), for which the Court itself has stopped in analysis. Article 121, the third paragraph of the Convention, clarifies the distinction between islands and rocks, specifying that the latter (i.e. rocks) may not have an EEA or a continental shelf when uninhabited or engaged in economic activity.

International judicial theory and practice have shown that under the circumstances, an island can be given full effect, partial effect, no effect at all, but gains little maritime space in delimiting maritime areas. There are cases where the islands gained full effect, e.g. the delimitation of maritime space between the US and Mexico; Venezuela, and Great Britain (CC Decision 2010, point 106), and here, as a rule, the borderline passes between the islands belonging to both parties respectively. In other cases, the islands have profited partial or no effect but benefiting from a limited maritime space, or when neither effect nor maritime space. The Constitutional Court noted in the function of the principle of Equite that, from the Albanian side, in determining the borderline between Albania and Greece, the characteristics of the coast 
of both countries should have been taken into account, especially the presence of islands or rock masses in water areas an object of delimitation. Specifically, the Court considers that the delimitation process should have gone through several stages, leading to adopting a provisional borderline corrected because of the principle of Equity. In this sense, the influence of the inhabited islands of Lazareto, Erikuza, and Othonoi and the main island of Corfu itself had to be assessed separately. The Agreement gives (unjustly) to everyone full effect in the demarcation of the borderline (CC Decision 2010, 107). Another significant problem of the Agreement under consideration is the treatment of the rock mass or the Barketa hammer, which turns out to have also been given full effect, equating it with the Albanian continental soil, although we are dealing only with a small mass uninhabited rocky and without economic life. Moreover, this rock mass has significantly influenced the displacement of the borderline separating the territorial sea of the two countries. In analyzing all this, the Court finally considers that the Agreement concluded between the Republic of Albania and the Republic of Greece 'On the delimitation of their respective areas, the continental shelf and other maritime areas belonging to them under international law', is incompatible with the Constitution regarding issues related to a) the failure of the president of the Republic to provide the Albanian delegation with full powers for the conduct of negotiations and the conclusion of the Agreement; b) severe deficiencies in the content of the Agreement; c) non-application of the basic principles of international law for the division of maritime space between the two countries to achieve a fair and honest result; d) not taking into account the islands as particular circumstances in the delimitation of maritime spaces.

Based on all this, the Court decided: Declaration as incompatible with articles 3, 4, 7 and 92 of the Constitution, of the Agreement, concluded between the Republic of Albania and the Republic of Greece 'On the delimitation of their respective areas, the continental shelf and other maritime areas belonging to it under international law'. Following this, between the two states, mainly instigated by the Greek side, there have been occasional diplomatic and political talks and attempts published from the media in spring and summer 2021, in several political statements and diplomatic meetings between the parties for a review of the maritime borders at the International Court of Justice in The Hague. We understood that near or far as a road, depending on the will of their requests, what we know will be the sea border's future between the two neighboring states. 


\section{CONCLUSION}

Throughout history, Albania and Greece's relationship was always documented by international acts and accepted by both sides of the sea border as neighboring countries. Undoubtedly, the spirit of nationalism encountered not infrequently by both parties has damaged the confidence of rapprochement and cooperation between the two countries, giving unilateral approaches and conclusions on this issue of critical importance for the continuity of relations between the two countries. The evolution of this relationship reached the peak of the maritime border re-discussion in 2009 with a new agreement between the two countries rejected as incompatible with the Albanian constitution by the Constitutional Court in 2010 after reviewing the argument that the deal in question is null. No has produced new legal effects, which means that the borders between the two states are according to the previously accepted and documented regulation. Meanwhile, after this decision, the parties discuss in 2021 entrusting the maritime border issue to the International Court of Justice in The Hague. As an international mechanism for resolving the conflict, its decision is what will be next in the future of the sea borders for both countries. 


\section{REFERENCES}

1. Archive of the Ministry of Foreign Affairs, 1923. file 136, 9/1.

2. Archive of the Ministry of Foreign Affairs, 1958. file 6.

3. Caflisch, Lucius. 1997. Maritime Boundaries Delimitation: Encyclopedia of Public International Law. Vol.11, 213.

4. Decision of the Constitutional Court, 2010. 10, 15.3, 35, 47, 48, 52, 63, 82.3, 88, 98, 106, 107.

5. Decree of People's Assembly, No. 5384. 1976.

6. Dushku, Ledia. 2012."When history divided two cross-border countries Albania and Greece, 1912-1914. Tirane,252.

7. International Court of Justice Decision Romania/Ukraine, 2009, para. 217.

8. Kondis, Basilis. 1976. "Greece and Albania 1908-1914", Thessaloniki,98.

9. Law 9861, 2008. On the control and surveillance of the state border. art.53.

10. Treaty of Friendship, Cooperation, Good Neighborliness and Security between the Republic of Albania and the Greek Republic, 1996. art.1.

11. Murati Shaban, 2013, "Albanian diplomacy in search of identity". Enea Publications: Tirane, 32.

12. Official Journal of Republic of Albania, 2010. Publication of the Official Centre of Publications, 52.

13. Poincaré, Raymond. 2006. "First and Second Balkan War and London Conference 1912-1913. Logos: Tirane,494.

14. Puto, Arben. 2001. "Albanian issue in international acts after first world war", Albin Publications: Tirane. 85.

15. Shigeru, Oda. 1995. "Exclusive Economic Zone". Encyclopedia of Public International Law, Vol.2,305.

16. UNCLOSart.33/1, 33/2, 56/1, 86. https://treaties.un.org/doc/publication/unts/volume\%201155/volume-1155-i18232-english.pdf

17. Vienna Convention on the law of treaties, 1969. art.7, art 8 www.un.org/depts/los/convention_agreements/texts/unclos/unclos_e.pdf)

18. Zaganjori, Xhezair. 2021. "Inter Gentes", Morava: Tirane,184. 